\title{
PENGELOLAAN LIMBAH MEDIS COVID 19 MELALUI KEARIFAN LOKAL
}

\author{
Diah Pudjiastuti Email: diahpudjiastuti@iwu.ac.id \\ Prodi Ilmu Politik, International Women University \\ Dr. Yuniar Rahmatiar, S.H., M.H Email : yuniar@ubpkarawang.ac.id \\ Deny Guntara,S.H., M.H Email : deny.guntara@ubpkarawang.ac.id
}

Fakultas Hukum Universitas Buana Perjuangan Karawang

\begin{abstract}
ABSTRAK
Tujuan penelitian ini adalah untuk mengetahui apa yang menjadi kendala pemerintah dalam pengelolaan limbah medis Covid-19 melalui kearifan local dan untuk mengetahui upaya-upaya apa saja yang harus dilakukan oleh pemerintah dalam rangka pengelolaan limbah medis Covid 19 melalui kaerifan local. metode studi literatur dengan menelaah sumber-sumber referensi sebagai data sekunder tentang kearifan local dalam pengelolaan limbah medis Covid 19. Hasil penelitian menunjukan bahwa di lapanagan masih terdapat kendala dalam pengelolaan limbah medis COVID-19 melalui kearifan local. Berdasarkan hal tersebut maka harus ada upaya yang harus dilakukan oleh pemerintah dalam rangka pengelolaan limbah medis COVID-19 yaitu mengakomodirnya dalam peraturan daerah dan melakukan penyuluhan, serta adanya peran subervisi dalam meningkatkan peran serta masyarakat dalam rangka pengelolaan limbah medis COVID-19 melalui kearifan local.
\end{abstract}

\section{Kata Kunci : Limbah Medis, Covid 19, Kearifan Lokal}

\section{ABSTRACT}

The purpose of this study is to find out what are the government's obstacles in managing Covid-19 medical waste through local wisdom and to find out what efforts the government must make in the context of managing Covid-19 medical waste through local wisdom. method of literature study by examining reference sources as secondary data on local wisdom in the management of Covid 19 medical waste. The results show that in the field there are still obstacles in the management of COVID-19 medical waste through local wisdom. Based on this, efforts must be made by the government in the context of managing COVID-19 medical waste, namely accommodating it in regional regulations and conducting counseling, as well as the role of supervision in increasing community participation in the management of COVID-19 medical waste through local wisdom.

Keywords: Legal protection; Traditional Knowledge; Copyrights 
PENGELOLAAN LIMBAH MEDIS COVID 19 MELALUI KEARIFAN LOKAL: Diah Pudjiastuti, Yuniar Rahmatiar, Deny Guntara

PENDAHULUAN

Limbah medis di Indonesia tergolong ke dalam limbah B3 yang pengelolaannya diatur dalam Peraturan Pemerintah Nomor 101 Tahun 2014 tentang Pengelolaan Limbah Bahan Berbahaya dan Beracun. Pengelolaan limbah B3 dilakukan dengan prinsip kewaspadaan dan menggunakan metode pengelolaan limbah yang aman dan ramah lingkungan. Dibutuhkan perlakuan dan fasilitas khusus sejak limbah itu dihasilkan (from cradle) hingga dimusnahkan (to grave). ${ }^{1}$

Pandemi COVID-19 berdampak pada meningkatnya jumlah limbah medis sehingga membebani fasilitas pelayanan kesehatan. Pada bulan Maret 2020, limbah medis di Malaysia meningkat sebesar 10\% dari bulan sebelumnya. Di Jakarta meningkat sebesar $30 \%$, sementara di kota Wuhan terjadi peningkatan dari 40 ton menjadi 240 ton per hari. ${ }^{2}$ Kementrian Lingkungan Hidup dan Kehutanan (KLHK) mencatat sejak awal pandemic Covid-19

\footnotetext{
${ }^{1}$ Prasetiawan, T. (2020). Permasalahan Limbah Medis Covid-19 Di Indonesia. Info Singkat, 12(9).Hlm. 14

2 Yolarita, E., \& Kusuma, D. W. (2020). Pengelolaan Limbah B3 Medis Rumah Sakit Di Sumatera Barat Pada Masa Pandemi Covid19. Jurnal Ekologi Kesehatan, 19(3), Hlm. 149
}

masuk ke Indonesia pada Maret 2020 sampai awal Februari 2021 terdapat 5.417,95 ton timbunan limbah medis Covid$19 .^{3}$

\begin{tabular}{|c|}
\hline 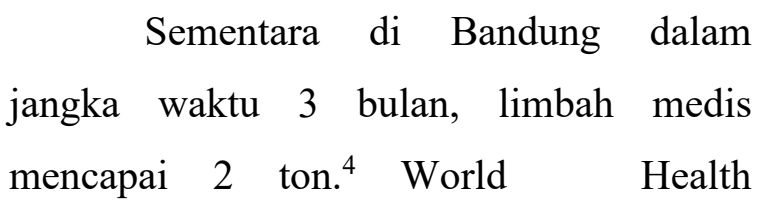 \\
\hline Organization (WHO) menjelaskan \\
\hline Coronaviruses (Cov) adalah virus \\
\hline menginfeksi sistem pernapasan. Infeksi \\
\hline virus ini disebut COVID-19. Virus \\
\hline $\begin{array}{l}\text { Corona menyebabkan penyakit flu biasa } \\
\text { sampai penyakit yang lebih parah }\end{array}$ \\
\hline seperti Sindrom \\
\hline Tengah (MERS-CoV) dan \\
\hline Pernafasan Akut Parah \\
\hline Virus ini menular dengan cepat dan \\
\hline ah menyebar ke beberapa \\
\hline
\end{tabular}

Dampak pandemi Covid-19 ini sangat luas, tidak saja di bidang kesehatan, namun juga di berbagai sector, seperti

$3 \quad$ Phttps://www.merdeka.com/peristiwa/klhkcatat-sejak-pandemi-terdapat-641795-tontimbunan-limbah-medis-covid.html, diakses pada tanggal 16 Juli 2021

4 https://www.pikiran-rakyat.com/bandungraya/pr-011337384/hanya-3-bulan-limbahmedis-di-bandung-mencapai-2-ton, diakses pada tanggal 16 Juli 2021

5 Hanoatubun, S. (2020). Dampak Covid-19 terhadap Prekonomian Indonesia. EduPsyCouns: Journal of Education, Psychology and Counseling, 2(1), Hlm. 149 
PENGELOLAAN LIMBAH MEDIS COVID 19 MELALUI KEARIFAN LOKAL: Diah Pudjiastuti, Yuniar Rahmatiar, Deny Guntara

pendidikan, perekonomian, politik, hukum dan pertahanan.

$$
\text { Masalah lingkungan hidup }
$$

mendapatkan perhatian besar warga dunia seiring dengan berkembangnya isu-isu kerusakan lingkungan. Setidaknya terdapat 15 (lima belas) isu lingkungan hidup yang menjadi perbincangan diberbagai pertemuan Internasional. Isu-isu lingkungan tersebut diantaranya adalah polusi, pemanasan global, over populasi, penipisan sumber daya alam, pembuangan limbah, hilangnya keanekaragaman hayati, deforestasi, asidifikasi laut, penipisan lapisan ozon, hujan asam, polusi air, urban sprawl, masalah kesehatan masyarakat, dan rekayasa genetik. Oleh karena itu, kesadaran atas lingkungan hidup harus meningkat karena menyangkut keberlangsungan hidup manusia. Manusia secara ekologis merupakan bagian dari lingkungan hidup, sehingga kerusakan pada lingkungan merupakan bagian dari kerusakan kehidupan manusia. $^{6}$

Prinsip pencegahan penularan penyakit infeksi adalah melalui pemutusan

6 Rachman, F. (2018). Konstruksi Partisipasi Warga Negara Dibidang Lingkungan Hidup Dalam Wacana Pembangunan Berkelanjutan: Studi Kasus Artikel Opini Media Massa Pada Surat Kabar Harian di Kota Medan (Doctoral dissertation, Universitas Pendidikan Indonesia).

Hlm. 1 rantai host/pejamu/ inang. Oleh karena itu, dalam menyikapi wabah Covid-19 ini, Perhimpunan Dokter Spesialis Penyakit Dalam Indonesia

(PAPDI) merekomendasikan memutuskan rantai host/pejamu/inang dengan berbagai cara. Pemutusan mata rantai penyebaran virus bisa dilakukan salah satunya dengan pengelolaan limbah medis infeksius dengan benar sesuai prosedur. Secara khusus, pengelolaan limbah medis diatur dalam PermenLHK No. P.56/Menlhk-Setjen/2015 tentang Tata Cara dan Persyaratan Teknis Pengelolaan Limbah B3 dari Fasilitas Pelayanan Kesehatan. ${ }^{7}$

Baru-baru ini adanya dugaan kasus limbah medis Covid-19 dibuang sembarangan, yakni Kepolisian Resor Bogor akan memanggil pihak yang terlibat kasus pembuangan limbah infeksius atau bahan berbahaya dan beracun (B3) medis dari Hotel tempat isolasi pasien Covid-19 tanpa gejala atau OTG di Kota Tanggerang. ${ }^{8}$ Dimana limbah medis Covid

\footnotetext{
7 Nugraha, C. (2020). Tinjauan Kebijakan Pengelolaan Limbah Medis Infeksius Penanganan Corona Virus Disease 2019 (Covid-19). Jurnal Untuk Masyarakat Sehat (JUKMAS), 4(2), Hlm. 217

8 https://regional.kompas.com/read/2021/02/ 11/15004721/kasus-limbah-medis-covid-19dibuang-sembarangan-polisi-pihak-hotelrakus?page $=$ all, diakses pada tanggal 16 Juli 2021
} 
PENGELOLAAN LIMBAH MEDIS COVID 19 MELALUI KEARIFAN LOKAL: Diah Pudjiastuti, Yuniar Rahmatiar, Deny Guntara

19 tersebut dibuang di Rest Area Tol dan di TPS. ${ }^{9}$

Limbah pelayanan kesehatan terutama limbah medis, apabila tidak dilakukan pengelolaan dengan benar akan menimbulkan potensi bahaya bagi kesehatan dan lingkungan. Pencemaran lingkungan yang terjadi akibat limbah medis akan kembali berdampak terhadap kesehatan baik perorangan maupun masyarakat sekitar. Potensi bahaya dari pengelolaan limbah medis sudah dapat terjadi mulai sejak pengumpulan, penampungan, pengangkutan dan pembuangan hingga pemusnahan. Beberapa pengaruh yang dapat ditimbulkan oleh keberadaan limbah ini adalah terjadinya pencemaran yang berdampak pada penurunan kualitas lingkungan dan terhadap kesehatan. Bahkan secara sederhana keberadaan limbah ini akan menimbulkan gangguan estetika, bau dan menjadi tempat perkembang biakan vektor serta binatang pengganggu. Gangguan genetik dan reproduksi dapat terjadi akibat limbah medis. Meskipun mekanisme gangguan belum sepenuhnya diketahui secara pasti,

9 Nugraha, C. (2020). Tinjauan Kebijakan Pengelolaan Limbah Medis Infeksius Penanganan Corona Virus Disease 2019 (Covid-19). Jurnal Untuk Masyarakat Sehat (JUKMAS), 4(2), Hlm. 217 namun beberapa senyawa dapat menyebabkan gangguan atau kerusakan genetik dan sistem reproduksi manusia misalnya pestisida (untuk pemberantasan lalat, nyamuk, kecoa, tikus dan serangga atau binatang pengganggu lain) dan bahan radioaktif. ${ }^{10}$

Mengingat dampak kerusakan lingkungan yang ditimbulkan, maka penerapan sanksi baik pidana maupun perdata serta pemberian denda maksimal dinilai belum efektif mengatasi masalah lingkungan, untuk itu diperlukan usaha kerjasama antara Pemerintah dan masyarakat dalam mengembangkan potensi dari kearifan lokal. Misalnya melalui kebijakan-kebijakan yang berupaya untuk memperkuat, melestarikan serta merawat kearifan lokal sebagai sarana pencegahan kerusakan lingkungan.

Kearifan lokal merupakan sebuah sistem alam tatanan kehidupan sosial, politik, budaya, ekonomi serta lingkungan yang hidup di tengah-tegah masyarakat lokal. Ciri yang melekat dalam kearifan tradisional adalah sifatnya yang dinamis, berkelanjutan dan dapat diterima oleh komunitasnya. ${ }^{11}$

10 Rosihan, A. (2018). Pengelolaan Limbah Medis Pelayanan Kesehatan. Hlm. 11-13

11 Husni Thamrin, Kearifan Lokal Dalam Pelestariaan Lingkungan (The Lokal Wisdom 
PENGELOLAAN LIMBAH MEDIS COVID 19 MELALUI KEARIFAN LOKAL: Diah Pudjiastuti, Yuniar Rahmatiar, Deny Guntara

Berdasarkan uraian tersebut diatas, maka yang menjadi permasalahan untuk diteliti adalah pertama, apa yang menjadi kendala pemerintah dalam pengelolaan limbah medis Covid-19 melalui kearifan local dan kedua, upaya-upaya apa saja yang harus dilakukan oleh pemerintah dalam rangka pengelolaan limbah medis Covid 19 melalui kaerifan local. Berdasarkan uraian dalam latar belakang yang telah dirumuskan, maka secara keseluruhan tujuan dari penelitian ini adalah untuk mengetahui apa saja kendala dan upaya yang harus dilakukan dalam pengelolaan limbah medis Covid 19 berdasarkan kearifan local.

Penelitian terdahulu yang berkaitan atau mendekati judul dari permasalahan yang diangkat yang mendukung penelitian ini adalah sebagai berikut:

1.Muhammad Senna Hastoanggoro, Universitas Trisakti pada tahun 2021 dengan judul Skripsi Desain Kendaraan Pengolah Limbah Medis Covid-19;

2.Niki Tri Nurwahyuni, Laila Fitria, Olce Umboh, Dismo Katiandagho, Universitas Indonesia, Dinas Kesehatan Daerah Provinsi Sulawesi Utara, Jurusan Kesehatan Lingkungan Poltekes,Kemenkes Manado, Pada tahun 2020 dengan judul jurnal

In Environmental Sustainable), Khutubkhanah Vol. 16 No. 1 Januari - Juni 2013, Hlm. 46
Pengelolaan Limbah Medis Covid-19 Pada Rumah Sakit.

Perbedaan mendasar antara tulisan ini dengan kedua tulisan ilmiah tersebut di atas terletak pada obyek penelitian mengenai limbah medis Covid-19, dimana penelitian yang pertama terkait dengan pengolahan limbah medis yang terintegrasi dengan kendaraan dan penelitian kedua terkait dengan pengelolaan limbah medis pada Rumah Sakit rujukan yang ada di Provinsi Sulawesi Utara pada bulan MeiJuni 2020, sedangkan dalam tulisan ini, penulis akan mengkaji mengenai apa saja kendala dan upaya yang harus dilakukan dalam pengelolaan limbah medis Covid 19 berdasarkan kearifan local.

\section{METODE PENELITIAN}

Penelitian ini menggunakan metode studi literatur dengan menelaah sumber-sumber referensi sebagai data sekunder tentang kearifan local dalam pengelolaan limbah medis Covid 19. Berdasarkan data tersebut, kemudian dikompilasikan, dianalisis dan ditarik kesimpulan.

\section{PEMBAHASAN}

\begin{tabular}{|c|c|c|}
\hline 1.Kendala & Pemerintah & Dalam \\
\hline Pengelolaan & Limbah Medis & Covid-1 \\
\hline
\end{tabular}


PENGELOLAAN LIMBAH MEDIS COVID 19 MELALUI KEARIFAN LOKAL: Diah Pudjiastuti, Yuniar Rahmatiar, Deny Guntara

Mempertahankan kearifan lokal bukan hal yang mudah, banyak kendalakendala yang harus dihadapi terutama dampak globalisasi, media sosial / teknologi yang tanpa disadari mempengaruhi nilainilai moral dan kesadaran pentingnya melestarikan kearifan lokal harus dihadapi secara arif dan bijaksana. Krisis lingkungan dengan segala aspek yang menjadi penyebabnya, terutama kepentingan politik dan ekonomi menjadikannya bukan suatu hal yang mudah untuk ditaati. Apalagi jika penegak hukumnya pun memiliki pemahaman hukum yang sangat dangkal dan disertai dengan moral yang kurang terpuji, tentu penegakan hukum akan sampai pada krisis yang semakin sulit diatasi. Seperti kasus-kasus lingkungan yang dibawa ke pengadilan "kandas" di tengah jalan dan tidak jelas penyelesaian selanjutnya. ${ }^{12}$ Posisi kearifan lokal saat ini berada dalam posisi yang lemah. Arus kapitalisme lebih mendominasi dalam sendi-sendi kehidupan komunitas masyarakat. Dalam pandangan kapitalisme, analisis untung dan rugi lebih dominan dan

12 Muhammad Akib, Penegakan Hukum Lingkungan Dalam Perspektif HolistikEkologis, Graha Ilmu, Yogyakarta, 2015, Hlm. 77 lebih penting daripada dari mana sumber pengetahuan tersebut berasal. ${ }^{13}$

Kearifan lokal dipandang sangat bernilai dan mempunyai manfaat tersendiri dalam kehidupan masyarakat. Sistem tersebut dikembangkan karena adanya kebutuhan untuk menghayati, mempertahankan, dan melangsungkan hidup sesuai dengan situasi, kondisi, kemampuan, dan tata nilai yang dihayati di dalam masyarakat yang bersangkutan. Dengan kata lain, kearifan lokal tersebut kemudian menjadi bagian dari cara hidup mereka yang arif untuk memecahkan segala permasalahan hidup yang mereka hadapi. Berkat kearifan lokal mereka dapat melangsungkan kehidupannya, bahkan dapat berkembang secara berkelanjutan (sustainable development). ${ }^{14}$

Kearifan local memerlukan suatu usaha untuk menjaga lingkungan hidup guna mempertahankan eksistensinya. Usaha tersebut harus disertai dengan kesadaran akan peranan kearifan local yang sangat

13 Thamrin, H. (2013). Kearifan lokal dalam pelestarian lingkungan (the lokal wisdom in environmentalsustainable). Kutubkhanah, 16(1), Hlm. 46

14 Suparmini, S., Setyawati, S., \& Sumunar, D. R. S. (2013). Pelestarian lingkungan masyarakat Baduy berbasis kearifan lokal. Jurnal Penelitian Humaniora, 18(1). Hlm. 11 
PENGELOLAAN LIMBAH MEDIS COVID 19 MELALUI KEARIFAN LOKAL: Diah Pudjiastuti, Yuniar Rahmatiar, Deny Guntara

penting dalam menghadapi permasalahan serta tidak merusak lingkungan hidup itu sendiri. $^{15}$

Undang-Undang No. 32 Tahun 2009 memberikan pengertian tentang kearifan lokal, yaitu nilai-nilai luhur yang berlaku dalam tata kehidupan masyarakat untuk antara lain melindungi dan mengelola lingkungan hidup secara lestari. Kesadaran untuk melindungi lingkungan hidup, nyata dengan dimasukkannya ketentuan-ketentuan perlindungan lingkungan hidup dan konservasi sumberdaya alam hayati dan ekosistemnya di darat maupun di laut pada semua peraturan perundang-undangan yang mengatur tentang sumberdaya alam, sesuai sektor masing-masing. Bahkan konsep pembangunan yang dilakukan negaranegara di dunia termasuk Indonesia sebagai negara yang sangat bergantung pada sumberdaya alam, diarahkan agar dalam segala usaha pendayagunaannya tetap memperhatikan keseimbangan lingkungan hidup serta kelestarian fungsi dan kemampuannya sehingga di samping dapat memberikan manfaat sebesar-besarnya bagi

${ }^{15}$ Wibowo, H. A., Wasino, W., \& Setyowati, D. L. (2012). Kearifan lokal dalam menjaga lingkungan hidup (Studi kasus masyarakat di Desa Colo Kecamatan Dawe Kabupaten Kudus). Journal of Educational Social Studies, 1(1). Hlm. 26 kesejahteraan rakyat, tetapi bermanfaat atau dirasakan juga oleh generasi mendatang. ${ }^{16}$

Pengelolaan limbah B3 Fasyankes di era COVID-19 memiliki tantangan tersendiri. Limbah B3 medis adalah barang atau bahan sisa hasil kegiatan medis yang tidak digunakan kembali yang berpotensi terkontaminasi oleh zat yang bersifat infeksius atau kontak dengan pasien dan/atau petugas di Fasyankes yang menangani pasien COVID-19. Adapun diantaranya meliputi masker bekas, sarung tangan bekas, perban bekas, tisu bekas, plastik bekas minuman dan makanan, kertas bekas makanan dan minuman, alat suntik bekas, set infus bekas, Alat Pelindung Diri (APD) bekas, sisa makanan pasien dan lainlain, berasal dari kegiatan pelayanan di Unit Gawat darurat (UGD), ruang isolasi, ruang Intensive Care Unit (ICU), ruang perawatan, dan ruang pelayanan lainnya. ${ }^{17}$

Pemerintah mengeluarkan edaran mengenai cara pengolahan limbah infeksius APD melalui Surat Edaran Menteri Lingkungan Hidup dan Kehutanan

${ }^{16}$ Siombo, M. R. (2011). Kearifan Lokal dalam Perspektif Hukum Lingkungan. Jurnal Hukum Ius Quia Iustum, 18(3), Hlm. 432

17 Sitompul, P. P. E. (2021). Menilik kebijakan pengolahan limbah B3 fasilitas pelayanan kesehatan selama pandemi COVID-19 di Provinsi Jawa Barat. Dinamika Lingkungan Indonesia, 8(1), Hlm. 73 
PENGELOLAAN LIMBAH MEDIS COVID 19 MELALUI KEARIFAN LOKAL: Diah Pudjiastuti, Yuniar Rahmatiar, Deny Guntara

Nomor SE.2/MENLHK/PSLB3/PLB.3 /2020 tanggal 24 Maret 2020 tentang Pengelolaan Limbah Infeksius (Limbah B3) Dan Sampah Rumah Tangga Dari Penanganan Corona Virus Disease (Covid19). Dalam edaran tersebut dijelaskan langkah-langkah penanganan limbah infeksius di rumah tangga sebagai berikut (Menteri Lingkungan Hidup dan Kehutanan, 2020), yakni mengumpulkan limbah infeksius APD berupa masker, sarung tangan, dan baju pelindung, masker medis sebelum dibuang diharuskan untuk digunting terlebih dahulu untuk menghindari penyalahgunaan, mengemas terpisah dari sampah lainnya di dalam wadah tertutup yang bertuliskan, Limbah Infeksius, limbah infeksius diambil oleh petugas dari dinas yang bertanggungjawab melakukan pengambilan dari setiap sumber, kemudian diangkut ke lokasi pengumpulan yang telah ditentukan sebelum diserahkan ke pengolah limbah B3 dan petugas kebersihan dan pengelola sampah wajib menggunakan APD seperti masker, sarung tangan, dan safety shoes yang setiap hari didisinfeksi. Dalam edaran tersebut juga disebutkan bahwa pemerintah daerah mempunyai kewajiban untuk menyiapkan tempat sampah/drop boxkhusus masker di ruang publik. ${ }^{18}$

Berdasarkan ketentuan tersebut, maka dapat dipahami bahwa pengelolaan limbah medis COVID-19 memerlukan penanganan yang berbeda dengan limbah lainnya, seperti dengan sampah rumah tangga bagi pasien yang menjalani isolasi mandiri di Rumah. Oleh karena itu diperlukan peran pemerintah dalam penanganan pengelolaan limbah medis COVID-19 ini mulai dari pengangkutan hingga proses pembuangan akhir. Namun pada kenyataannya, petugas pengangut sampah yang datang seminggu sekali ke lingkungan masyarakat tidak menggunakan APD dengan benar, selain itu kesadaran masyarakat pun masih tampak kurang dengan tidak memisahkan sampah rumah tangga dan sampah bekas penanganan pasien COVID-19, padahal limbah medis tersebut dapat ditangani dengan adanya kesadaran masyarakat untuk melakukan pemilahan, pewadahan, desinfeksi serta pelabelan, namun hal ini tampak tidak berjalan dengan baik, artinya masih ada kendala dilapangan dalam hal pengelolaan

\footnotetext{
${ }^{18}$ Laelasari, E. (2021). Manajemen Pengelolaan Limbah Medis Rumah Tangga Era Pandemi Covid-19 Di Indonesia: Narrative Literature. Prosiding Penelitian Pendidikan dan Pengabdian 2021, 1(1), Hlm. 449-450
} 
PENGELOLAAN LIMBAH MEDIS COVID 19 MELALUI KEARIFAN LOKAL: Diah Pudjiastuti, Yuniar Rahmatiar, Deny Guntara

limbah medis COVID-19. Selain di masyarakat, fenomena belum sesuainya pengelolaan limbah medis COVID-19 juga terjadi di Rumah Sakit pemerintahan, seperti pengelolaan limbah medis padat APD di RSUD Suryah Khairudin belum $\begin{array}{lll}\text { sesuai dengan } & \text { KMK }\end{array}$ No.HK.01.07/MENKES/537/2020, yaitu tidak adanya label keterangan "biohazard" pada wadah yang digunakan tahap pemilahan dan pewadahan, petugas pengangkut yang tidak memakai APD lengkap pada tahap pengangkutan, dan TPS yang belum memenuhi standar Permen LHK P56 Tahun 2015. ${ }^{19}$

Selain, itu pemerintah juga telah mengeluarkan Surat Edaran No. SE.2/MENLHK/PSLB3/PLB.3/3/2020 tentang Pengelolaan Limbah Infeksius (Limbah B3) dan Sampah Rumah Tangga Dari Penanganan Corona Virus Disease (COVID-19). Dimana pelaksanaan dalam penanganan limbah infeksius dan pengelolaan sampah rumah tangga dari penanganan Covid-19, dilakukan langkahlangkah penanganan sebagai berikut : 1 . Limbah infeksius yang berasal dari fasilitas

19 Ainii, S. (2021). ANALISIS SISTEM PENGELOLAAN LIMBAH MEDIS PADAT ALAT PELINDUNG DIRI (APD) DI FASILITAS KHUSUS ISOLASI COVID-19 RSUD SURYAH KHAIRUDIN (Doctoral dissertation, Universitas Jambi). Hlm. 1 pelayanan kesehatan a. Melakukan penyimpanan limbah infeksius dalam kemasan yang tertutup paling lama 2 (dua) hari sejak dihasilkan b. Mengangkut dan/atau memusnahkan pada pengolahan Limbah B3 : 1) Fasilitas insinerator dengan suhu pembakaran minimal $8000 \mathrm{C}$; atau 2) Autoclave yang dilengkapi dengan pencacah (shredder) c. Residu hasil pembakaran atau cacahan hasil autociave dikemas dan dilekati simbol "Beracun" dan label Limbah B3 yang selanjutnya disimpan ditempat penyimpanan sementara limbah B3 untuk selanjutnya diserahkan kepada pengelola Limbah B3. 2. Limbah infeksius dari ODP yang berasal dari rumah tangga : a. Mengumpulkan limbah infeksius berupa limbah APD antara lain berupa masker, sarung tangan dan baju pelindung diri; $b$. Mengemas tersendiri dengan menggunakan wadah tertutup; c. Mengangkut dan memusnahkan pada pengolahan Limbah B3; d. Menyampaikan informasi kepada masyarakat tentang pengelolaan limbah infeksius yang bersumber dari masyarakat, sebagai berikut : 1) Limbah APD antara lain berupa, masker, sarung tangan, baju pelindung diri, dikemas tersendiri dengan menggunakan wadah tertutup yang bertuliskan "Limbah Infeksius"; 2) Petugas dari dinas yang bertanggungjawab dibidang 
PENGELOLAAN LIMBAH MEDIS COVID 19 MELALUI KEARIFAN LOKAL: Diah Pudjiastuti, Yuniar Rahmatiar, Deny Guntara

lingkungan hidup, kebersihan dan kesehatan melakukan pengambilan dari setiap sumber untuk diangkut ke lokasi pengumpulan yang telah ditentukan sebelum diserahkan ke pengolah Limbah B3. 3. Pengelolaan sampah rumah tangga dan sampah sejenis sampah rumah tangga : a. Seluruh petugas kebersihatan atau pengangkut sampah wajib dilengkapi dengan APD khususnya masker, sarung tangan dan safety shoes yang setiap hari harus disucihamakan; b. Dalam upaya mengurangi timbalan sampah masker, maka kepada masyarakat yang sehat dihimbau untuk menggunakan masker guna ulang yang dapat dicuci setiap hari; c. Kepada masyarakat yang sehat dan menggunakan masker sekali pakai (disposable mask) diharuskan untuk merobek, memotong atau menggunting masker tersebut dan dikemas rapi sebelum dibuang ketempat sampah untuk menghindari penyalahgunaan; dan $\mathrm{d}$. Pemerintah daerah menyiapkan tempat sampah/drop box khusus masker diruang publik. $^{20}$

${ }^{20}$ Hesti, Y. (2020). Upaya Penanganan Limbah B3 Dan Sampah Rumah Tangga Dalam Mengatasi Pandemi Corona Sesuai Dengan Surat Edaran No. Se. 2/Menlhk/Pslb3/Plb. 3/3/2020tentang Pengelolaan Limbah Infeksius (Limbah B3) Dan Sampah Rumah Tangga Dari Penanganan Corona Virus Disease (Co. Jurnal Pro Justitia, 1(2), Hlm. 64
Penanganan pengelolaan limbah medis COVID-19 sangat penting diperhatikan sebagaimana pandangan Menteri Kesehatan Terawan Agus Putranto yang mengatakan bahwa limbah medis berbahaya dan beracun bagi kesehatan manusia dan lingkungan. Oleh karena itu Menteri Kesehatan Terawan Agus Putranto mengingatkan agar Pemda mengembangkan pengelolaan limbah medis sesuai kemampuan dan kearifan local daerah setempat. ${ }^{21}$

Untuk dapat melakukan pengelolaan limbah medis COVID-19 melalui kearifan local, maka sebaiknya kita memahami terlebih dahulu serta membuat solusi atas permasalahan yang menjadi kendala dalam menggunakan kearifan local. Adapun kendala-kendala yang dihadapi dalam mencegah kerusakan lingkungan melalui kearifan lokal, diantaranya yaitu :

a)Sedikit demi sedikit budaya lokal tereliminasi oleh arus modernisasi dan globalisasi;

b)Terjadinya konflik atau benturan antara nilai-nilai kearifan lokal dengan nilai-nilai baru yang datang dari luar;

21 https://nasional.kompas.com/read/2020/11/ 13/10281651/terawan-kelola-limbah-medissesuai-syarat-untuk-cegah-penyebaran-covid-19, diakses pada tanggal 17 Juli 2021 
PENGELOLAAN LIMBAH MEDIS COVID 19 MELALUI KEARIFAN LOKAL: Diah Pudjiastuti, Yuniar Rahmatiar, Deny Guntara

c)Dalam pembangunan masyarakat cenderung memilih nilai yang baru datang (modern) karena dianggap dapat menambah penghasilan, pengalaman dll.

d)Daerah membuat penggalian objek wisata dengan kurangnya menyelaraskan dengan nilai-nilai yang hidup di dalam masyarakat dalam rangka otonomi daerah yang memajukan pemasukan daerah dan menghindari sebutan daerah tertinggal.

e)Kurangnya pengaturan hukum lingkungan yang kurang memberikan batasan yang jelas mengenai pola-pola pemanfaatan yang berkeadilan dan upaya pelestariannya.

f)Kurangnya kesadaran pelaku ekonomi untuk bertanggungjawab memikul beban atau potensi dampak negatif dari proses produksi yang ditimbulkan.

g)Adanya dampak jangka panjang dan penemuan dampak tidak langsung dari kerusakan lingkungan;

h)biaya pemulihan perbaikan kerusakan lingkungan sangat besar.

i)Penanggulangan polusi udara / pollutan yang belum efektif.

j)Pengaturan penegakan hukum lingkungan masih ditemukan dualisme pemahaman terhadap kasus-kasus kerusakan lingkungan seperti misalnya pembakaran hutan yang jelas dilarang namun ada juga yang mengatur dibolehkan membuka lahan dengan cara membakar dengan luas lahan tertentu.

k)Lemahnya penegakan hukum lingkungan. 1)Menurunnya moral atau sikap peduli terhadap lingkungan, seperti tidak menghargai alam dan merusak lingkungan.

m)Peningkatan jumlah penduduk yang berimplikasi pada meningkatnya kebutuhan akan lahan.

n)Kebiasaan membuang sampah sembarangan, sehingga menyebabkan pencemaran lingkungan dan menyebabkan banjir.

\section{Upaya-Upaya Apa Saja Yang Harus} Dilakukan Oleh Pemerintah Dalam Rangka Pengelolaan Limbah Medis Covid 19 Melalui Karifan Local

Kearifan lokal adalah pandangan hidup dan ilmu pengetahuan serta berbagai strategi kehidupan yang berwujud aktivitas yang dilakukan oleh masyarakat lokal dalam menjawab berbagai masalah dalam pemenuhan kebutuhan mereka. Dalam bahasa asing sering juga dikonsentrasikan sebagai kebijakan setempat "local wisdom" atau pengetahuan setempat "local Knowledge" atau kecerdasan setempat "local Genius". 22

22 https://www.djkn.kemenkeu.go.id/kpknlpalu/baca-artikel/13057/Memaknai-Kembali- 
PENGELOLAAN LIMBAH MEDIS COVID 19 MELALUI KEARIFAN LOKAL: Diah Pudjiastuti, Yuniar Rahmatiar, Deny Guntara

Melakukan upaya-upaya pengembangan maupun pelestarian melalui berbagai macam cara yang ada maka nilai-nilai kearifan tersebut dapat bertahan keberadannya dan tidak menghilang dengan mudah. Bentuk pengembangan ataupun pelestarian kearifan lokal tersebut, diantaranya terwujud dalam bentuk penggunaan bahan/material, sistem struktur dan konstruksi, teknologi yang digunakan, iklim dan lingkungan setempat, kondisi lahan, bahkan hingga ke sosial buaya yang mempengaruhi wujud dari artefak fisik tersebut. $^{23}$

Menurut Sartini, peran dan fungsi kearifan lokal adalah: ${ }^{24}$

a)Untuk konservasi dan pelestarian sumber daya alam;

b)Pengembangan sumber daya manusia;

Kearifan-Lokal-Dalam-Kehidupan-Seharihari.html, diakses pada tanggal 17 Juli 2021

${ }^{23}$ Verawati Ade, Idrus Affandi, Implementasi Nilai-Nilai Kearifan Lokal Dalam Mengembangkan Keterampilan Kewarganegaraan (Studi Deskriftif Analitik Pada Masyarakat Talang Manak Kec. Rakit Kulim, Kab. Indragiri Hulu Provinsi Riau, Jurnal Pendidikan Ilmu Sosial, Vol 25 No. 1, 2016, Hlm. 85

${ }^{24}$ H. Iin Wariin Basyari, Nilai-Nilai Kearifan Lokal (Local Wisdom) Tradisi Memitu Pada Masyarakat Cirebon (Studi Masyarakat Desa Setupatok Kecamatan Mundu), Edunomic, Jurnal Vol. 2 No. 1, 2014, Hlm. 48
c)Pengembangan kebudayaan dan ilmu pengetahuan;

d)Sebagai sumber petuah/ kepercayaan/ sastra dan pantanagan;

e)Sebagai sarana membentuk membangun integrasi komunal;

f)Sebagai landasan etika dan moral;

g)Fungsi politik.

Berdasarkan hal tersebut diatas dalam mencegah kerusakan lingkungan melalui upaya kearifan lokal diperlukan hal - hal yang harus diperhatikan yaiti nilai konservatif. Nilai konservatif adalah kolot atau bersikap mempertahankan keadaan yang sudah ada, kebiasaan dan tradisi yang berlaku saat ini. ${ }^{25}$ Saam yang dikutip oleh Amri menyebutkan bahwa kearifan lokal itu berkembang dalam kehidupan sehari-hari melalui ajaran langsung dari orang tua kepada anaknya maupun dari ninik mamak kepada cucu kemenakannya. Adapun cara lain dalam penyampaian kearifan lokal tersebut melalui petatah-petitih, pantang larang dan sastra lain. ${ }^{26}$ Jadi, kearifan lokal

\footnotetext{
25 Agus Sudaryanto, Nilai-Nilai Kearifan Lokal Yang Diterapkan Dalam Pengelolaan Tanah Pariwisata Sri Gethuk Di Bleberan, Playen, Gunung Kidul, Mimbar Hukum Vol. 30 No. 1, 2018, Hlm. 86

${ }^{26}$ Deni Fatma Sari, Kearifan Lokal Masyarakat Dalam Melestarikan Batang Aie Lunang Di Kenagarian Lunag Kecamatan Lunang Kabupaten Pesisir Utara, https://media.neliti.com/media/publications/131
} 
PENGELOLAAN LIMBAH MEDIS COVID 19 MELALUI KEARIFAN LOKAL: Diah Pudjiastuti, Yuniar Rahmatiar, Deny Guntara

ini bukan hanya menyangkut pengetahuan dan pemahaman masyarakat adat tentang manusia dan bagaimana relasi yang baik diantara manusia, melainkan juga menyangkut pengetahuan, pemahaman dan adat kebiasaan tentang manusia, alam dan bagaimana relasi diantara semua penghuni komunitas ekologis ini harus di bangun sehingga diharapkan menuju pengelolaan sumber daya alam dan lingkungan kearah yang lebih baik. ${ }^{27}$

Untuk menyerap dan mentranformasikan kearifan lokal dalam sistem hukum formil maka hal yang paling logis adalah mengakomodirnya dalam peraturan daerah. Undang-undang Pemerintah Daerah menghendaki dan mewajibkan adanya partisipasi masyarakat dalam pembentukan Perda, begitupun Undang-Undang Keterbukaan Informasi Publik yang menghendaki keterlibatan, peran serta dan partisipasi di tingkat daerah, termasuk peraturan daerah yang dimaksud

475-ID-kearifan-lokal-masyarakat-dalammelestar.pdf, Hlm. 36

${ }^{27}$ Deni Fatma Sari, Kearifan Lokal Masyarakat Dalam Melestarikan Batang Aie Lunang Di Kenagarian Lunag Kecamatan Lunang Kabupaten Pesisir Utara, https://media.neliti.com/media/publications/131 475-ID-kearifan-lokal-masyarakat-dalammelestar.pdf, Hlm. 36 dalam Undang-Undang Pembentukan Peraturan Perundang-Undangan. ${ }^{28}$

Operasionalisasi kebijakan dan strategi dalam rangka pelestarian dan pengembangan kearifan lokal harus diupayakan secara lebih terpadu dan berkelanjutan dengan mensinergikan antara aspek budaya serta aspek strategis lainnya melalui pengarus utamaan prinsip-prinsip dan nilai budaya daerah dalam proses penyelenggaraan penataan ruang di tingkat pemerintah pusat, provinsi, kabupaten dan kota sesuai dengan semanagat desentralisasi dan otonomi daerah. ${ }^{29}$

Kearifan lokal harus dilestarikan dalam suatu masyarakat guna menjaga keseimbangan antara pemanfaatan sumber daya alam dengan lingkungan sekaligus pelestariannya. ${ }^{30}$ Sebagaimana yang amanat Pasal 32 ayat (1) UUD 1945 yang menyebutkan bahwa :"Negara memajukan kebudayaan nasional Indonesia di tengah peradaban dunia dengan menjamin

${ }^{28}$ Eko Noer Kristiyanto, Kedudukan Kearifan Lokal Dan Peranan Masyarakat Dalam Penataan Ruang Di Daerah, Jurnal Rechtsvinding Vol 6 No. 2, 2017, Hlm. 168

${ }^{29}$ Eko Noer Kristiyanto, Kedudukan Kearifan Lokal Dan Peranan Masyarakat Dalam Penataan Ruang Di Daerah, Jurnal Rechtsvinding Vol 6 No. 2, 2017, Hlm. 168

${ }^{30}$ Deny Hidayati, Memudarnya Nilai Kearifan Lokal Masyarakat Dalam Penghelolaan Sumber Daya Air, Jurnal Kependudukan Indonesia, Vol. 11 No. 1, 2016, Hlm. 48 
PENGELOLAAN LIMBAH MEDIS COVID 19 MELALUI KEARIFAN LOKAL: Diah Pudjiastuti, Yuniar Rahmatiar, Deny Guntara

kebebasan masyarakat dalam memelihara dan mengembangkan nilai-nilai budayanya". Pengertian yang tersirat dalam pasal tersebut membuktikan bahwa ada keinginan yang sangat kuat bagi bangsa Indonesia untuk memajukan ilmu pengetahuan dan budaya serta memelihara dan mengembangkan nilai-nilai budaya. Kebudayaan dapat digolongkan menjadi dua komponen utama yaitu kebudayaan material dan kebudayaan non-material. Kebudayaan material mengacu pada semua ciptaan masyarakat yang konkret, termasuk temuantemuan yang dihasilkan dari penggalian arkeologis. Kebudayaan non-material adalah ciptaan abstrak yang diwariskan dari satu generasi ke generasi berikutnya, misalnya berupa dongeng, cerita rakyat, adat istiadat, tarian tradisional dan lain sebagainya. ${ }^{31}$

Asas keterbukaan dan peran serta masyarakat merupakan hal yang sangat penting dalam pembangunan berkelanjutan berwawasan lingkungan, terutama dalam proses administrasi perizinan lingkungan dan AMDAL sebagai instrumen pencegahan pencemaran lingkungan. Selain itu pendidikan lingkungan bertujuan untuk

31 Hafidz Putra Arifin, Politik Hukum Perlindungan Cagar Budaya Di Indonesia, Dialogia Juridica Jurnal Hukum Bisnis Dan Investasi, Vol. 10 No. 1, 2018, Hlm. 66 meningkatkan kesadaran, kepedulian tentang lingkungan dengan segala permasalahannaya dan dengan pengeahuan, keterampilan, sikap motivasi dan komitmen untuk bekerja secara individu dan kolektif terhadap pemecahan permasalahan dan mempertahankan kelestarian fungsi-fungsi lingkungan. Maka hal-hal yang perlu diperhatikan dalam pendidikan lingkungan adalah:

a)Memberikan kesempatan bagi setiap individu untuk memperoleh pengertian dasar tentang lingkungan hidup, permasalahannya serta peran dan tanggung jawab manusia dalam upaya melestarikan fungsi-fungsi lingkungan hidup.

b)Membantu individu dan masyarakat mengembangkan keterampilan yang dibutuhkan dalam pengelolaan, menjaga kelestarian fungsi-fungsi lingkungan dan memecahkan permasalahan lingkunagan.

c)Memupuk kesadaran dan kepekaan terhadap lingkungan hidup dan permasalahannaya, melalui penyuluhan terhadap individu atau masyarakat tentang sistem nilai, kepekaan yang kuat atas kepedulian tentang lingkungan dan motivasi untuk secara aktif berfartisifasi terhadap pelestarian fungsi-fungsi lingkungan dan pencegahan kerusakan lingkungan. 
PENGELOLAAN LIMBAH MEDIS COVID 19 MELALUI KEARIFAN LOKAL: Diah Pudjiastuti, Yuniar Rahmatiar, Deny Guntara

Maka pendidikan lingkungan perlu memenuhi dua kebutuhan masyarakat yang terkait, yaitu :

a)Mengembangkan sumber daya manusia yang berkemampuan teknis yang dilengkapi dengan pengetahuan yang mendalam, keterampilan yang dibutuhkan untuk menilai (asses) dan mengelola lingkungan;

b)Menumbuhkan sikap dan perilaku pada masyarakat yang peka dan bertanggungjawab terhadap lingkungan.

Kebutuhan pertama diarahkan pada pemecahan masalah-masalah lingkungan sedangkan kebutuhan kedua diarahkan pada peningkatan keampuhan public pressure dalam mempertahankan kelestarian fungsifungsi lingkungan dan mencegah kerusakan lingkungan. ${ }^{32}$

Kualitas lingkungan hidup perlu diartikan tidak saja bagi manusia sebagai faktor biotis dalam kompleksitas proses ekologi biosfera, tetapi juga sebagai makhluk sosial berbudidaya dan segi-segi hukum untuk lingkungan hidup perlu mencakup bimbingan dalam kedua segi ini secara luas. ${ }^{33}$

32 Muhamad Erwin, Hukum Lingkungan Dalam Sistem Kebijaksanaan Pembangunan Lingkungan Hidup, Refika Aditama, Bandung, 2009, Hlm. 58-59

33 Badan Pembinaan Hukum Nasional, SegiSegi Dari Pengelolaan Lingkungan Hidup, Binacipta, 1977, Hlm. 243
Manusia dengan lingkungan alam sekitarnya merupakan satu kesatuan yang tidak terpisahkan. Akan tetapi, hubungan yang terjalin antara keduanya tidak hanya terwujud sebagai suatu hubungan ketergantungan manusia terhadap lingkungannya. Namun demikian juga terwujud sebagai suatu hubungan yang memperlihatkan bahwa manusia dapat mempengaruhi dan melihat, mengintreprestasi, menghadapi, memanfaatkan, dan mendayagunakan lingkungan alam dan lingkungan fisik tempatnya hidup untuk memenuhi berbagai kebutuhan serta meraih kesejahteraan hidup, kebudayaan sangat berperan disini. ${ }^{34}$

Berdasarkan hal tersebut, maka terhadap pengelolaan limbah medis COVID-19 melalui kearifan lokal, pemerintah dapat melakukan berbagai upaya, diantaranya yaitu:

a)Menjungjung tinggi ilmu-ilmu agama karena agama mengajarkan untuk menjaga lingkungan dan melarang untuk merusaknya. b)Mewajibkan kurikulum pembelajaran baik secara formal maupun infoemal melalui muatan lokal untuk memberikan

34 Departemen Pendidikan Dan Kebudayaan, Peranan Nilai Budaya Daerah Dalam Upaya Pelestarian Lingkungan Hidup, CV. Kidang Mas, Jawa Barat, 1998, Hlm. 81 
PENGELOLAAN LIMBAH MEDIS COVID 19 MELALUI KEARIFAN LOKAL: Diah Pudjiastuti, Yuniar Rahmatiar, Deny Guntara

pendidikan kepada siswa tentang pentingnya melestarikan lingkungan melalui kearifan lokal mengingat dampak globalisasi yang ditimbulkan;

c)Pemerintah harus tegas dan konsisten terhadap penegakan penanggulanan bahan berbahaya (B3) yang diatur di dalam Pasal 69 ayat (1) huruf c Undang-undang No. 32 Tahun 2009 Tentang Perlindungan dan Pengelolaan Lingkungan Hidup (UU PPLH) dan Pasal 39 ayat (2) Undang-undang No. 18 Tahun 2008 Tentang Pengelolaan Sampah, sebagaimana penemuan inkonsistensi Pemerintah dilihat dari banyaknya kasus import limbah B3, dimana pengaturan hukum mengimpor limbah B3 merupakan tindak pidana. Selain itu Pemerintah harus menyempurnakan atau mengharmonisasi regulasi yang menimbulkan multitafsir seperti halnya pelarangan import limbah B3 yang diatur di UU PPLH dan UU Pengelolaan sampah yang bertentangan dengan Pasal 50 ayat (1) dan Pasal 50 ayat (2) Undang-undang No. 7 Tahun 2014 tentang Perdagangan. Kekosongan hukum tersebut antara lain oleh UU PPLH dan UU Pengelolaan sampah terkait import limbah B3 dilarang secara tegas namun di dalam Pasal UU Perdaganagan tersebut yang menjadi persoalannya adalah aturan di bidang perdagangan, impor limbah bahan baku plastik diperbolehkan dengan pembatasan, sehingga hal tersebut menimbulkan multitafsir.

d)Melakukan pengawasan atas pelaksanaan peraturan, misalnya memberikan penerangan/penjelasan/penyuluhan secara merata dan berkesinambungan yang disampaikan secara terang, lugas dan bijak sehingga masyarakat paham serta sadar dan peduli terhadap lingkungannya.

e)Pemerintah melibatkan partisipasi masyarakat dalam pengambilan keputusan. Dengan adanya kontrol dari masyarakat, diharapkan lebih komitmen dan peduli dalam upaya menjaga kelestarian lingkungan. Sehingga diperlukan suatu sistem koordinasi dan komunikasi yang baik agar kepentingan-kepentingan masyarakat dapat terakomodasi.

f)Adanya suatu badan yang mensupervisi pencegahan dini yang mengelola informasi terkait pencegahan kerusakan lingkungan. Dimana informasi tersebut harus pasti diterima dan dipahami serta informasi tersebut tepat waktu.

g)Perlu dilakukan rehabilitasi lingkungan secara terus menerus terutama terkait pencemaran udara karena pencemaran udara merupakan pencemaran yang terus-menerus dan berlangsung lama. 
PENGELOLAAN LIMBAH MEDIS COVID 19 MELALUI KEARIFAN LOKAL: Diah Pudjiastuti, Yuniar Rahmatiar, Deny Guntara

h)Pengawasan terhadap indistri-industri terkait rehabilitasi lingkungan dan pemerintah harus segera mendapatkan ilmu pengetahuan pengendali limbah terkait penanggulangan limbah B3. Sehingga perusahaan dapat memanajemen dampak kerusakan lingkungan serta menggunakan sumber daya alam secara efisien.

i)Perlu meningkatkan kualitas hidup / mutu hidup melalui kesederhanaan dan kemandirian dalam bidang ekonomi.

j)Pembangunan harus memperhatikan kapasitas daya dukung lingkungan, efisiensi dalam pengalokasian sumberdaya dan ruangnya serta nilai-nilai yang hidup di masyarakat seperti nilai kebersamaan/ gotong royong, nilai religius dll.

k)Pemerintah menanggulangi masalah pencemaran secara bertahap dan berkelanjutan (menyelesaikan "PR" ) terhadap pencemaran-pencemaran dan kerusakan lingkungan yang terjadi seperti membangun IPAL komunal dalam menangani pencemaran air, dll sehingga kualitas lingkungan hidup baik abiotik, biotik maupun sosial tetap terjaga.

1)Kearifan lokal menjadi pertimbangan dalam putusan Hakim baik perkara pidana maupun perdata sehingga terwujud ketertiban dan ketentraman dalam masyarakat.

\section{KESIMPULAN}

Pengelolaan limbah medis COVID19 memerlukan penanganan yang berbeda dengan limbah lainnya, seperti dengan sampah rumah tangga bagi pasien yang menjalani isolasi mandiri di Rumah. Oleh karena itu diperlukan peran pemerintah dalam penanganan pengelolaan limbah medis COVID-19 ini mulai dari pengangkutan hingga proses pembuangan akhir. Namun pada kenyataannya, petugas pengangut sampah yang datang seminggu sekali ke lingkungan masyarakat tidak menggunakan APD dengan benar, selain itu kesadaran masyarakat pun masih tampak kurang dengan tidak memisahkan sampah rumah tangga dan sampah bekas penanganan pasien COVID-19, padahal limbah medis tersebut dapat ditangani dengan adanya kesadaran masyarakat untuk melakukan pemilahan, pewadahan, desinfeksi serta pelabelan, namun hal ini tampak tidak berjalan dengan baik, artinya masih ada kendala dilapangan dalam hal pengelolaan limbah medis COVID-19. kendala dalam menggunakan kearifan local yang harus segera ditangani oleh pemerintah, agar pengelolaan limbah medis COVID-19 dapat berjalan sesuai dengan kearifan local. 
PENGELOLAAN LIMBAH MEDIS COVID 19 MELALUI KEARIFAN LOKAL: Diah Pudjiastuti, Yuniar Rahmatiar, Deny Guntara

Untuk menyerap dan

mentranformasikan kearifan lokal dalam sistem hukum formil maka hal yang paling logis adalah mengakomodirnya dalam peraturan daerah. Undang-undang Pemerintah Daerah menghendaki dan mewajibkan adanya partisipasi masyarakat dalam pembentukan Perda, begitupun Undang-Undang Keterbukaan Informasi Publik yang menghendaki keterlibatan, peran serta dan partisipasi di tingkat daerah, termasuk peraturan daerah yang dimaksud dalam Undang-Undang Pembentukan Peraturan Perundang-Undangan. Berdasarkan hal tersebut, maka pemerintah perlu melakukan berbagai upaya yang tentunya harus adanya sinkronisasi tujuan antara pemerintah dengan masyarakatnya melalui upaya antara lain harus meningkatkan kesadaran masyarakat yang tinggi akan bahayanaya limbah medis COVID-19 serta berperan serta dalam melakukan pengelolaan limbah medis COVID-19, saat ini berbagai peraturan perundang-undangan telah mengatur mengenai pengelolaan limbah medis atai zat B3 melalui kearifan local, namun dalam tataran implementasinya belum berjalan dengan optimal. Sehingga pentingnya suatu peran yang mensubvervisi seluruh program dengan meningkatkan pengawasan dan evaluasi serta penegakan hukum yang tegas dan professional.

\section{DAFTAR PUSTAKA}

\section{A.Buku}

Badan Pembinaan Hukum Nasional, SegiSegi Dari Pengelolaan Lingkungan Hidup, Binacipta, 1977

Departemen Pendidikan Dan Kebudayaan, Peranan Nilai Budaya Daerah Dalam Upaya Pelestarian Lingkungan Hidup, CV. Kidang Mas, Jawa Barat, 1998

Muhamad Erwin, Hukum Lingkungan

Dalam Sistem Kebijaksanaan Pembangunan Lingkungan Hidup, Refika Aditama, Bandung, 2009

Muhammad Akib, Penegakan Hukum Lingkungan Dalam Perspektif Holistik-Ekologis, Graha Ilmu, Yogyakarta, 2015

\section{B.Sumber Lainnya}

\section{Jurnal}

Agus Sudaryanto, Nilai-Nilai Kearifan Lokal Yang Diterapkan Dalam Pengelolaan Tanah Pariwisata Sri Gethuk Di Bleberan, Playen, Gunung Kidul, Mimbar Hukum Vol. 30 No. 1, 2018

Ainii, S. (2021). ANALISIS SISTEM PENGELOLAAN LIMBAH 
PENGELOLAAN LIMBAH MEDIS COVID 19 MELALUI KEARIFAN LOKAL: Diah Pudjiastuti, Yuniar Rahmatiar, Deny Guntara

MEDIS PADAT ALAT

PELINDUNG DIRI (APD) DI

FASILITAS KHUSUS ISOLASI COVID-19 RSUD SURYAH

KHAIRUDIN (Doctoral dissertation,

Universitas Jambi).

Deny Hidayati, Memudarnya Nilai Kearifan

Lokal Masyarakat Dalam

Penghelolaan Sumber Daya Air,

Jurnal Kependudukan Indonesia,

Vol. 11 No. 1, 2016

Eko Noer Kristiyanto, Kedudukan Kearifan

Lokal Dan Peranan Masyarakat Dalam Penataan Ruang Di Daerah, Jurnal Rechtsvinding Vol 6 No. 2, 2017

H. Iin Wariin Basyari, Nilai-Nilai Kearifan Lokal (Local Wisdom) Tradisi Memitu Pada Masyarakat Cirebon (Studi Masyarakat Desa Setupatok Kecamatan Mundu), Edunomic, Jurnal Vol. 2 No. 1, 2014

Hafidz Putra Arifin, Politik Hukum Perlindungan Cagar Budaya Di Indonesia, Dialogia Juridica Jurnal Hukum Bisnis Dan Investasi, Vol. 10 No. 1,2018

Hanoatubun, S. (2020). Dampak Covid-19 terhadap Prekonomian Indonesia. EduPsyCouns: Journal of
Education, Psychology and

Counseling, 2(1)

Hesti, Y. (2020). Upaya Penanganan Limbah B3 Dan Sampah Rumah Tangga Dalam Mengatasi Pandemi Corona Sesuai Dengan Surat Edaran No. Se. 2/Menlhk/Pslb3/Plb. 3/3/2020tentang Pengelolaan Limbah Infeksius (Limbah B3) Dan Sampah Rumah Tangga Dari Penanganan Corona Virus Disease (Co. Jurnal Pro Justitia, 1(2)

Husni Thamrin, Kearifan Lokal Dalam Pelestariaan Lingkungan (The Lokal Wisdom In Environmental Sustainable), Khutubkhanah Vol. 16 No. 1 Januari - Juni 2013

Laelasari, E. (2021). Manajemen Pengelolaan Limbah Medis Rumah Tangga Era Pandemi Covid-19 Di Indonesia: Narrative Literature. Prosiding Penelitian Pendidikan dan Pengabdian 2021, 1(1)

Nugraha, C. (2020). Tinjauan Kebijakan Pengelolaan Limbah Medis Infeksius Penanganan Corona Virus Disease 2019 (Covid-19). Jurnal Untuk Masyarakat Sehat (JUKMAS), 4(2) 
PENGELOLAAN LIMBAH MEDIS COVID 19 MELALUI KEARIFAN LOKAL: Diah Pudjiastuti, Yuniar Rahmatiar, Deny Guntara

Prasetiawan, T. (2020). Permasalahan Limbah Medis Covid-19 Di Indonesia. Info Singkat, 12(9).

Rachman, F. (2018). Konstruksi Partisipasi Warga Negara Dibidang Lingkungan Hidup Dalam Wacana Pembangunan Berkelanjutan: Studi Kasus Artikel Opini Media Massa Pada Surat Kabar Harian di Kota Medan (Doctoral dissertation, Universitas Pendidikan Indonesia).

Rosihan, A. (2018). Pengelolaan Limbah Medis Pelayanan Kesehatan.

Siombo, M. R. (2011). Kearifan Lokal dalam Perspektif Hukum Lingkungan. Jurnal Hukum Ius Quia Iustum, 18(3)

Sitompul, P. P. E. (2021). Menilik kebijakan pengolahan limbah B3 fasilitas pelayanan kesehatan selama pandemi COVID-19 di Provinsi Jawa Barat. Dinamika Lingkungan Indonesia, 8(1)

Suparmini, S., Setyawati, S., \& Sumunar, D. R. S. (2013). Pelestarian lingkungan masyarakat Baduy berbasis kearifan lokal. Jurnal Penelitian Humaniora, 18(1).

Thamrin, H. (2013). Kearifan lokal dalam pelestarian lingkungan (the lokal wisdom in environmental sustainable). Kutubkhanah, 16(1)

Verawati Ade, Idrus Affandi, Implementasi Nilai-Nilai Kearifan Lokal Dalam Mengembangkan Keterampilan Kewarganegaraan (Studi Deskriftif Analitik Pada Masyarakat Talang Manak Kec. Rakit Kulim, Kab. Indragiri Hulu Provinsi Riau, Jurnal Pendidikan Ilmu Sosial, Vol 25 No. 1,2016

Wibowo, H. A., Wasino, W., \& Setyowati, D. L. (2012). Kearifan lokal dalam menjaga lingkungan hidup (Studi kasus masyarakat di Desa Colo Kecamatan Dawe Kabupaten

Kudus). Journal of Educational Social Studies, 1(1).

Yolarita, E., \& Kusuma, D. W. (2020). Pengelolaan Limbah B3 Medis Rumah Sakit Di Sumatera Barat Pada Masa Pandemi Covid19. Jurnal Ekologi Kesehatan, 19(3)/

Website

Deni Fatma Sari, Kearifan Lokal Masyarakat Dalam Melestarikan Batang Aie Lunang Di Kenagarian Lunag Kecamatan Lunang Kabupaten Pesisir Utara, https://media.neliti.com/media/publi 
PENGELOLAAN LIMBAH MEDIS COVID 19 MELALUI KEARIFAN LOKAL: Diah Pudjiastuti, Yuniar Rahmatiar, Deny Guntara

cations/131475-ID-kearifan-lokal-

masyarakat-dalam-melestar.pdf,

https://metro.tempo.co/read/1433841/limba

h-medis-covid-19-dibuang-di-rest-

area-tol-dan-tps-pelaku-ditangkap,

diakses pada tanggal 16 Juli 2021

https://nasional.kompas.com/read/2020/11/1

3/10281651/terawan-kelola-limbah-

medis-sesuai-syarat-untuk-cegah-

penyebaran-covid-19, diakses pada

tanggal 17 Juli 2021

https://regional.kompas.com/read/2021/02/1

1/15004721/kasus-limbah-medis-

covid-19-dibuang-sembarangan-

polisi-pihak-hotel-rakus? page $=$ all,

diakses pada tanggal 16 Juli 2021

https://www.djkn.kemenkeu.go.id/kpknl-

palu/baca-artikel/13057/Memaknai-

Kembali-Kearifan-Lokal-Dalam-

Kehidupan-Sehari-hari.html, diakses

pada tanggal 17 Juli 2021

https:/www.merdeka.com/peristiwa/klhk-

catat-sejak-pandemi-terdapat-

641795-ton-timbunan-limbah-

medis-covid.html, diakses pada

tanggal 16 Juli 2021

https://www.pikiran-rakyat.com/bandung-

raya/pr-011337384/hanya-3-bulan-

limbah-medis-di-bandung-

mencapai-2-ton, diakses pada

tanggal 16 Juli 2021 